\title{
FREQUENCY OF IMPLEMENTATION AND IMPACT OF APPENDECTOMY AT ACTIVATION OF THE PATHOLOGICAL PROCESS IN PATIENTS WITH CHRONIC NON-ATROPHIC GASTRITIS
}

DOI: 10.36740/WLek202007133

\author{
Anatoly A. Avramenko \\ PETRO MOHYLA BLACK SEA NATIONAL UNIVERSITY, NIKOLAEV, UKRAINE
}

\begin{abstract}
The aim: Determine the frequency of surgery-appendectomy of patients with chronic non-atrophic gastritis and the impact of this transaction on the pathogenesis of chronic gastritis.

Materials and methods: Data of disease history and life were analyses, as well as the results of a comprehensive survey of 245 patients with chronic non-atrophic gastritis. Comprehensive examination included: step-by-step pH-metry, esophagogastroduodenoscopy, helicobacter infection test (HP) (helicobacter urease test and microscopic examination of stained smears), histological investigations of the gastric stump mucous.

Results: Helicobacter infection was detected in 100\% of cases. It was found that 56 (22.9\%) of patients were subjected to appendectomy. Age of patients, who had an appendectomy ranged from 4 to 40 years and averaged $18.34 \pm 1.05$ years, and the first pathological manifestations of the gastro-intestinal tract appeared in an average of $28.27 \pm 1.75$ year, i.e. in 10 years. As for the age qualification pupil were the earliest pathological manifestations appeared in a group of patients from 11 to 15 years (13 people (23.2\%) and amounted to about 6 years after the operation, and $6(46.2 \%)$ patients, manifestations appeared in 2-6 months after surgery; the most recent is in group from 16 to 20 years (19 people $(33.9 \%)$ and amounted to about 14 years $(\mathrm{p}<0.05)$.

Conclusions: Surgery on the body of immune system - appendix provokes activation of latent form of chronic non-atrophic gastritis, especially during puberty.
\end{abstract}

KEY WORDS: chronic non-atrophic gastritis, the immune system of the human body, appendectomy

Wiad Lek. 2020;73(7):1489-1491

\section{INTRODUCTION}

The condition of immune system is the key to curbing the development of pathological processes in the human body, so any intervention in its function is fraught with the development of different diseases. Appendicular process is part of the immune system, since it, like in the tonsils, formation of B-lymphocytes, which are the basis of humoral immunity $[1,2,3,4,5,6,7,8,9]$. Appendectomy remains the most common surgery: a year in the US, up to 250.000 appendectomies $[10,11,12]$. In the available for us literature there was no information on how appendectomy effects on the activation and development of chronic non-atrophic gastritis, which was the reason for our research.

\section{THE AIM}

Determine the frequency of surgery-appendectomy of patients with chronic non-atrophic gastritis and the impact of this transaction on the pathogenesis of chronic gastritis.

\section{MATERIALS AND METHODS}

On the basis of the clinical division of the problem lab on chronic Helicobacter pylori infection of the Petro Mohyla Black Sea National University data of disease history and life were analyses, as well as the results of a comprehensive survey of 245 patients with chronic non-atrophic gastritis. The age of patients ranged from 25 to 61 years (the medium age was $38.3 \pm 1.45)$; males $(80.4 \%)$ were 197 , female -48 (19.6\%).

Primary comprehensive survey included: step-by-step intragastric $\mathrm{pH}$-Metry based on methodology by Chernobrovii V.N esophagogastroduodenoscopy(EGDS) by generally accepted method, double HP testing: test for ureaz activity and microscoping stained by Giemsa smears, material for which was taken during endoscopy from 4 topographical zones: from the middle third of the gastric antrum and body of stomach on the big and small curvature with our created methodology and also histological studies of the gastric mucosa, the material for which is taken from the same zone, using a generally accepted method taking into account recent classification [13].

The study was conducted in accordance with the basic bioethical provisions of the Helsinki Declaration of the World Medical Association on the ethical principles of scientific 549 medical research involving human (19642008) and the order of the Ministry of Health of Ukraine No. 690 dated September 23, 2009, which was confirmed by the findings of the meeting of the Ethical Commission of Petro Mohyla Black Sea National University, Nikolaev

No. 5 dated May 15, 2019. 
Table I. Level of acidity of the patients with chronic non-atrophic gastritis

\begin{tabular}{ccc}
\hline \multirow{2}{*}{ The level of acidity } & \multicolumn{2}{c}{ The number of surveyed patients with chronic non-atrophic gastritis ( $=\mathbf{2 4 5}$ ) } \\
\cline { 2 - 3 } & Number of patients & \% \\
\hline Hyperacidity expressed & 24 & 9,8 \\
\hline Hyperacidity moderate & 35 & 14,3 \\
\hline Normacidity & 108 & 44,1 \\
\hline Hypoacidity moderate & 47 & 19,2 \\
\hline Hypoacidity expressed & 31 & 12,6 \\
\hline Anacidity & 0 & 0 \\
\hline
\end{tabular}

Note: $n$-the number of studies

Table II. Degree of semination of gastric mucosa with HP infection on topographical zones of patients with chronic non-atrophic gastritis

Topographic zones of stomach

Antrum of the stomach

Body of stomach
Degree of semination of gastric mucosa with HP infection on topographical zones of stomach

$(+) /(M \pm M)(n=245)$

a) $2,25 \pm 0,20$; б) $2,18 \pm 0,20$.

a) $2,15 \pm 0,20$; 6) $2,13 \pm 0,20$.

Note: $n$-the number of studies, a) large curvature, b) small curvature

Table III. Age of patients during appendectomy and beginning of the first pathological manifestations after surgery $(n=56)$

\begin{tabular}{ccccc}
\hline $\begin{array}{c}\text { Age qualification in the } \\
\text { operation period }\end{array}$ & Number & $\%$ & $\mathbf{M} \pm \mathbf{M}$ (year) & $\begin{array}{c}\text { First pathological manifestations } \\
\mathbf{M} \pm \mathbf{m} \text { (year) }\end{array}$ \\
\hline Before 10 years & 7 & 12,5 & $6,57 \pm 0,83$ & $17,29 \pm 2,49$ \\
\hline From 11 to 15 years & 13 & 23,2 & $13,38 \pm 0,31$ & $19,77 \pm 2,91$ \\
\hline From 16 to 20 years & 19 & 33,9 & $18,21 \pm 0,25$ & $32,58 \pm 1,80$ \\
\hline From 21 to 25 years & 7 & 12,5 & $22,85 \pm 0,49$ & $30,57 \pm 2,94$ \\
\hline Older then 25 years & 10 & 17,9 & $30,10 \pm 1,34$ & $37,20 \pm 4,21$ \\
\hline
\end{tabular}

Note: $n$-the number of studies

Primary sequence survey: first patients conducted pH-metry and then EGDS with biopsy material for testing in HP and histological studies of the stomach mucosa. The study was conducted in the morning on an empty stomach, in 12-14 hours after the last meal. The data obtained were processed statistically using Student $t$-test with the computation of averages $(\mathrm{m})$ and perhaps the likelihood of deviations $(\mathrm{m})$. The changes were considered to be statistically significant at $\mathrm{p}<0.05$. Statistical calculations were performed using Excel tables for Microsoft Office.

\section{RESULTS AND DISCUSSION}

Data obtained during the conduct of $\mathrm{pH}$-testing are shown in table I.

When carrying out the EGDS active ulcerous process in the duodenal ulcer was diagnosed at $11(4.5 \%)$, and 23 (9.4\%) patients had manifestations of carried in the past ulcers duodenal bulb as scar deformity of varying degrees of severity. When analyzing data of histological investigations of all patients in $100 \%$ of cases, have confirmed the existence of chronic non-atrophic gastritis in both active and inactive stages of varying degrees of severity.
When testing on HP Helicobacter infection was detected in $100 \%$ of cases when the degree for semination from $(+)$ to $(+++)$. Data on the extent of the gastric mucosa for semination of HP infection on topographical zones of the stomach patients with chronic non-atrophic gastritis are reflected in table II.

During comparative analysis of data on the medium level semination with HP infection of gastric mucosa on topographical zones reliable differences weren't found ( $p>0.05)$.

When analyzing data by frequency of held appendectomies it was found that $56(22.9 \%)$ patients had such an operation. Data on the age of patients during appendectomy and age, when we started the first pathological manifestations of the gastro-intestinal tract after operation, are presented in table III.

Age of patients, who had an appendectomy ranged from 4 to 40 years and averaged $18.34 \pm 1.05$ years, and the first pathological manifestations of the gastro-intestinal tract appeared in an average of $28.27 \pm 1.75$ year, i.e. in 10 years. As for the age qualification pupil were the earliest pathological manifestations appeared in a group of patients from 11 to 15 years and amounted to about 6 years after the operation, and $6(46.2 \%)$ patients, manifestations appeared in 2-6 months after surgery; the most recent is in group from 16 to 
20 years and amounted to about 14 years $(\mathrm{p}<0.05)$. The first manifestations in the form of proved chronic gastritis was 42 (75\%), duodenal ulcer-7 (12.5\%), acute pancreatitis-4 (7.2\%) chronic colitis-2 (3.6\%), cholelithiasis-1 (1.7\%) patient.

These results are understandable from the point of view of age qualification of having appendectomy. The period from 11 to 15 years is the period of puberty, when hormonal changes are destabilizing the immune system $[3,14$, 15]. Operative intervention during this period on the body of immune system strengthen this process that leads to activation of Helicobacter pylori infection, because of the two constraints-immunity and acid-peptic factor the first crashes that allows HP infection use more their energy for reproduction The increase in mass of $\mathrm{HP}$ infection activates the inflammatory process in the stomach lining which leads to a primary manifestation of chronic non-atrophic gastritis, which up to this point could be latent [16].

\section{CONCLUSIONS}

Surgery on the body of immune system - appendix provokes activation of latent form of chronic non-atrophic gastritis, especially during puberty.

\section{REFERENCES}

1. Tavrog M.L. Morfofunkcionalnaya harakteristika sistemy mestnogo specificheskogo immuniteta cherveobraznogo otrostka cheloveka v grudnom periode ontogeneza [Morphofunctional characteristic of the system of local specific immunity of the human appendix in the thoracic period of ontogenesis]. Ukrayinskij morfologichnij almanah. 2011; T.9,3(dodatok): 45-46. (In Russian).

2. Tumanov A.V. Razvitie vtorichnyh limfoidny organov [The development of secondary lymphoid organs]. Immunologiya. 2004; T.25, 2: 120-128. (In Russian).

3. Haitov R.M. Fiziologiya immunnoj sistemy [Physiology of the immune system]. M., 2001.223 s. (In Russian).

4. Yarilin A.A. Gomeostaticheskie processy v immunnoj sisteme. Kontrol chislennosti limfocitov: medicinskie aspekty immuniteta [Homeostatic processes in the immune system. Lymphocyte control: medical aspects of immunity]. Immunologiya. 2004; T.25, 35: 32-320. (In Russian).

5. Kushnareva M.V., Vinogradova T.V., Keshishyan E.S. i dr. Osobennosti immunnogo statusa i sistemy interferona u detej rannego vozrasta [Features of the immune status and interferon system in young children]. Rossijskij vestnik perinatologii i pediatrii. 2016; 3: 12-21. (In Russian).

6. Vasilev A.G., Churilov L.P., Trashkov A.P.i dr. Evolyuciya immunnoj sistemy i regulyatornye effekty antitel [The evolution of the immune system and the regulatory effects of antibodies]. Citologiya. 2018; T.60, 2: 71-80. (In Russian).

7. Lushova A.A., Zheremyan E.A., Astahova E.A. i dr. Subpopulyacii V-limfocitov: funkcii molekulyarnye marker [Subpopulations of B-lymphocytes: functions of molecular markers.]. Immunologiya. 2019; T.40, 6: 63-76. (In Russian).

8. Kuklina E.M., Smirnova E.N., Bajdina T.V. i dr. V-limfocity kak antigenprezentiruyushie kletki pri autoimunnyh patologiyah [В-лимфоциты как антигенпрезентирующие клетки при аутоимунных патологиях]. Vestnik Permskogo nauchnogo centra. 2017; 3: 36-41. (In Russian).
9. Abaturov A.E., Agafonova E.A., Abaturova N.I. i dr. Evolyuciya i vozrastnye osobennosti vrozhdennoj iadaptivnoj immunnoj sistemy. Sovremennaya pediatriya [Evolution and age-related characteristics of the innate and adaptive immune system]. 2016; 3(75): 1-11. (In Russian).

10. Sazhin A.V., Kirienko A.I., Kurcer M.A. i dr. Ostryj appendicit u beremennyh [Acute appendicitis in pregnant women]. Hirurgiya. Zhurnal im. N.I. Pirogova. 2019; 1: 70-77. (In Russian).

11. Sokolov M.E., Gusejnov A.Z., Gusejnov T.A. i dr. Sovremennaya diagnostika ostrogo appendicita (obzor literatury) [Modern diagnosis of acute appendicitis (literature review)]. Vestnik novyh medicinskih tehnologij. 2017; T.24,4: 219-230. (In Russian).

12. Sovcov S.A. Ostryj appendicit. Klinika, diagnostika, lechenie [Acute appendicitis.Clinic, diagnosis, treatment].Chelyabinsk, 2016.196s. (In Russian).

13. Avramenko A.A. Dostovernost stul-testa pri testirovanii bolnyh hronicheskim helikobakteriozom pri nalichii aktivnyh i neaktivnyh form helikobakternoj infekcii na slizistoj zheludka [The reliability of the stool test when testing patients with chronic helicobacteriosis in the presence of active and inactive forms of helicobacter infection on the gastric mucosa]. Suchasna gastroenterologiya. 2014; 3 (77): 22 - 26. (In Russian).

14. Trocenko A.A. Osobennosti formirovaniya immuniteta na raznyh etapah zhiznennogo cikla cheloveka [Features of the formation of immunity at different stages of the human life cycle]. Biologicheskie nauki. 2015; 6 (37), 4.2: 40- 42. (In Russian).

15. Sheplyagina L.A., Kruglova I.V. Vozrastnye osobennosti immuniteta u detej [Age-specific features of immunity in children]. Rossijskij medicinskij zhurnal. 2009; 23: 1564. (In Russian).

16. Avramenko A.A., Gozhenko A.I., Gojdyk V.S. Yazvennaya bolezn (ocherki klinicheskoj patofiziologii) [Peptic ulcer (essays on clinical pathophysiology)]. Odessa:000 «RA «ART-V», 2008.304s. (In Russian).

The work is a fragment of research work «Development of information and communication technologies in the system of medical examinations of seamen", the state registration number 0109 U008375.

ORCID and contributionship:

Anatoly A. Avramenko: 0000-0002-9652-089X ${ }^{A, B, C, D, E, F}$

\section{Conflict of interest:}

The Author declare no conflict of interest.

\section{CORRESPONDING AUTHOR \\ Anatoly A. Avramenko \\ Petro Mohyla Black Sea National University \\ 68 Desantnikiv St., NIKOLAEV 54000, UKRAINE \\ tel: +380976371807 \\ e-mail:aaaheli@gmail.com}

Received: 18.12.2019

Accepted: 27.05 .2020

A - Work concept and design, B - Data collection and analysis, C - Responsibility for statistical analysis,

D-Writing the article, $\mathbf{E}$-Critical review, $\mathbf{F}-$ Final approval of the article 